LOMACHINSKA IRINA,

Doctor of Philosophical Sciences, Professor, Borys Grinchenko Kyiv University

\title{
VALUE ORIENTATIONS OF INFORMATION CULTURE AS A KEY FACTOR OF SOCIETY INFORMATION SECURITY
}

\begin{abstract}
The article is devoted to an analysis of the essence of information culture as the main factor of security of a social information system in the context of globalization challenges of today's information threats.

The essence of information culture is defined as the main means of the formation of an information worldview of society at all stages of information and communication revolutions. Value orientations of information culture are analyzed in the context of the formation of ideology of knowledge society, namely: free access to knowledge as a prerequisite for human dignity and freedom, opposition to the transformation of knowledge into a commodity, which generates a desire for a monopoly on information resources as a statement of power at all levels - personal, corporate, nationwide and international.
\end{abstract}

Key words: information society; society of knowledge; information culture; information system; information; information war; psychological war; information worldview.

Problem definition. Under present-day conditions of the development of information society, associated with an active development of global information technologies, a significant part of social activity of entire society and its individual members is transferred from objective reality space to virtual space, which creates brand new opportunities for communicative social interaction. The above processes do not only expand opportunities for creative self-realization of both individuals and society as a whole but also create hazards of global manipulation of public conscience and behavior. Taking into account the current globalization dynamics of telecommunication networks, it may be assumed that in future informative types of aggression will prevail.

Analysis of studies and publications. In the post-Soviet space, philosophical understanding of the information culture phenomenon focuses mainly on the necessity of its consideration at several levels: sociotechnical - as an ability to work with information, sociocultural - as a complex of material and spiritual achievements of society, which reflect a historically achieved level of its development; educational - as an ability to adequately assimilate new knowledge, a system of upbringing, education, scientific work and artistic creation etc. The variety of approaches to an analysis of the concept of information culture is a result of the ambivalent essence of the concept of information, which is analyzed in detail in modern Russian scientific thought (in particular, the works by A. Sokolov and K. Kolin).

The analysis of the information culture phenomenon in the context of transformations of modern information society as knowledge society made for the necessity of turning to ideas of theorists of modern information society - M. Castells and E. Toffler, who pinpointed attention not only on its advantages but also its hazards - global commercialization of knowledge, exacerbation of the economic imbalance between countries that are information monopolists and world community as a whole, lowering of the level of knowledge of society in the information glut context etc. The ideas of H.M. McLuhan not only define the understanding of the social communicative basis of the modern global society development but also emphasize a close relationship of the progress of information and communication technologies with the improvement of information warfare means and methods.

The purpose of the study is to highlight value orientations of information culture as a determining factor of society information security.

Presentation of the basic material. Modern information society appears as a logical consequence of globalization changes of modernity - the global integration process of economic, political and sociocultural factors of countries' activities. An analysis of the sociocultural basis of the information society operation identifies two main trends in its development: on the one hand, a cross-cultural interaction in the form of cultural diffusion is observed, which leads to a change of the traditional system of values at the everyday level, and on the other hand, adaptive defense mechanisms of culture are bolstered in the face of a danger of global unification in the process of cultural expansion. Mutual assimilation of culture elements, on the one hand, contributes to integration processes, mutual cultural exchange and enrichment, and on the other hand, is accompanied with development of ethnic self-consciousness.

As S. Huntington points out in this connection, when an identity crisis comes, the meaning of such concepts as blood and faith, religion and family becomes actualized. People unite with those who have similar roots, church, language, values and institutions and stand aback from those who are different [Huntington, 2005: 186]. Global integration into world socio-cultural space causes the erosion of the ethno-cultural basis of the identity of nations and the loss of a historically established unique cultural system of norms, traditions and values, while creating the ground for destruction of the essential foundations of their spiritual existence. 
In modern scientific thought, the information society phenomenon is considered primarily in terms of transformation of communication means as a logical result of the global information revolution, which led to the formation of a new type of society - the network one, where the exchange of information has no timing or spatial boundaries. Information in information society is not only the main resource of its economic, political and cultural development, it also actualizes the issue of its fundamental values. A. Sokolov defines information society as "intellectually developed liberal-democratic society that has achieved global informatization of social production and everyday life thanks to the powerful computer and communication base" [Sokolov, 2010: 329]. Its main feature is intellectualization of society since the development of such constituents of social intelligence as science, education, law and morality govern the operational level of society as a whole. Accordingly, modern information society is the one where the main prerequisite for human and state welfare is knowledge gained through unhindered access to information resources and the ability to work with information as the major social, economic and spiritual resource, the basic source of labor productivity and power.

All the while, modern information society does not automatically become knowledge society. The UNESCO World Report on Knowledge Society points out that the concept of information society is based on technological achievements while the concept of knowledge society implies wider social, ethnic and political parameters. Hence, "we must not allow that the revolution in the field of information technologies and communications result in the fact that it is considered as one single form of society, underpinned by the logic of narrowly technological determinism and fatalism" [UNESCO, 2005: 19]. Accordingly, knowledge society has to ensure social integration of each of its members and promote the development of new forms of solidarity for both, the present generation, and for the future. There should be no social exclusion in knowledge society because knowledge is public heritage which has to be an achievement for everyone. One of the main challenges of future knowledge society is a cognitive gap which combines results of the imbalance in access to information, education, research as well as specifics of cultural and linguistic diversity. The development disparity dynamics of the cognitive process in assessing the value of knowledge, regulation of access to the most important knowledge, a different educational and cultural training level of users as well as an imperfect legal system of using information resources give rise to a global imbalance in the international context between countries that are information leaders and outsiders. The active formation of new information economy poses a threat of excessive commercialization of knowledge, the latter becoming a "commodity" in the form of codified information and acting as a means of total control over the realization of power influence in political games both within an individual country and in the international arena.

According to K.K. Kolin, philosophical understanding of the concept of information implies two main approaches to analyzing its content - attributive (information as an integral feature of matter, which manifests itself in all objects of animate and inanimate nature) and functional (where information is a result of human consciousness performance). The author proposes the definition of information as "an objective feature of reality, which manifests itself in heterogeneity (asymmetry) of the distribution of matter and energy in space and time, in the running irregularity of all processes in the animate and inanimate nature world as well as in human society and consciousness" [Kolin, 2005: 45].

It should be noted that in Ukrainian regulatory documents the concept of information substantially represents a functional approach viewpoint: "any information and/or data which can be stored as a hard copy or presented in an electronic form"1 and "knowledge"2. Accordingly, all information systems, information communications and resources are formed with allowance for human capabilities to perceive, assimilate, process, use and transmit information in space and in time, and the main goal of information society has to be the promotion of the growth of an educational, professional and cultural level of man, realization of his/her creative potential.

Thus, the information factor of the civilization development has to aim at the unification of the world into an integrated system, where information in the form of knowledge is perceived as a global value that enables states, nations and social groups operating as holistic information systems, capable of turning the information obtained into knowledge in accordance with the adopted system of norms, values and beliefs which determine cognitive abilities and form social memory.

The indicated sociocultural transformations related to informatization of society actualize the problem of the necessity to form a new type of culture - the information one. Among the main sources of development of knowledge society UNESCO documents emphasize two main factors - expansion of human rights in the ability to assimilate information resources and bridging the digital divide. The variety of key attributes of the digital divide is actualized in the following factors: economic resources (limited investment in the information infrastructure), a geographical factor (an imbalance in network access of geographic regions), age related and gender based social parameters, education etc. All the above factors are a direct reflection of the information culture level of society and may serve as the main hitting points during information wars.

In the broadest sense, information culture characterizes the capability of a complex information system (the biological one i.e. man or the social one i.e. society) to efficiently operate. In this context, an information system should be understood as "a communicative system that provides communication and information processing" 3 . S. Rastorguev suggests naming "those systems that are changeable due to informational influence as information systems capable of self-learning" [Rastorguev, 1999: 219]; he attributes man, a people and state to such systems.

The ambivalence of the concept of information leads to a variety of approaches to understanding the essence of information culture. According to the attributive approach, the concept of information culture is inseparable from the concept of culture as a whole, which represents the multifaceted spiritual wealth acquired by mankind in the form of ideas, knowledge, skills and beliefs. Culture implies the existence of traditions and memory of society; its content embodies not only material and spiritual values but also methods and ways of their creation and use, typical for each stage of human history, i.e. certain labor and educational skills in both material production and science, art, education, upbringing etc. The level of cultural

\footnotetext{
1 Про інформацію: Закон України. URL: http://zakon5.rada.gov.ua/ laws/show/2657-12 (дата звернення: 25.09.2018).

2 ДСТУ ISO 5127: 2007. Словник термінів. Інформація та документація. Київ: Держспоживстандарт України, 2010. С.6.

${ }^{3}$ ДСТУ ISO 5127: 2007. Словник термінів. Інформація та документація. Київ: Держспоживстандарт України, 2010. С.7
} 
development is defined as a qualitative characteristic of a specific historical process of acquiring knowledge, the humanistic orientation of all life aspects of society.

It should be mentioned that in scientific thought of the post-Soviet space, the concept of information culture is viewed primarily in the context of the functional approach as: "a level of practical achievement of the maturity of information interaction and all informational relations in society, a degree of perfection in handling any necessary information with the use of new information and telecommunication technologies and their product - electronic information resources" [Vinarik, 2009: 6].

A. Sokolov links the issue of the essence of information culture to the typification of communication cultures historically established forms of social communication, which define the expression means - speech, writing, printing and information technology rather than the semantic dimension of communication messages [Sokolov, 2010: 312]. Hence, information culture is a prerequisite and a result of a level of information world-view, corresponding to historical conditions, which determines the meaning of person's life in the dimensions of new information reality, his/her beliefs, principles of cognition and a value system

The basis of operation of state as an information system and a weighty factor of its security is an established system of national information resources, which defines national social memory and consists of information assets of all the previous generations and new information that ensures further scientific, educational and cultural development. Commercialization of knowledge as a commodity and awareness of the inexhaustibility of information resources result in the fact that redistribution of power for the purpose of their control is carried out with the help of weapons of information type. Proceeding from the content and role of information in the modern world, H. M. McLuhan, analyzing the process of presenting the development of different types of communication technologies (oral, written, mechanical and electrical) in the forms of improving various weapons, draws a conclusion: "the very inclusiveness of information as a weapon becomes a daily reminder of the fact that politics and history should be transformed to a form of concretizing panhuman fraternity ... As a policy tool, modern war has begun to mean the existence and end of one society at the cost of excluding the other" [McLuhan, 2011: 177].

The concept of information war may be defined as a communication technology of influencing mass consciousness for the purpose of achieving an information advantage in implementing a national military strategy through acting upon information systems and information of the enemy while strengthening and protecting one's own information systems and information. S. Rastorguev defines information war as "explicit and hidden targeted information influences of information systems on each other, aimed at getting a certain benefit in the material sphere" [Rastorguev, 1999: 219]. Violation of protective barriers in the interaction of elements of a complex system results in its reprogramming or destruction.

Simple (technical) systems of targeted collection of information are disabled by overloading or computer viruses. In case of man as a complex information system informational influence aims to disorient the system through activation of desires, thoughts and provoking actions aimed at self-destruction. The main task of information wars is disorientation of information and communication flows, which leads to manipulation of public consciousness, aimed at reprogramming of the information system in favor of the invader. Any information war therefore ends in favor of a higher-class system (with better means of accumulating, processing and storing information). The main feature of information weapon (propaganda, program-mathematical, psychological etc.) is its connection with information as its fundamental element and as the basic element of an objective selected for destruction. The strategy of using information weapon is entirely offensive, hence one may assume that the amount of information purposefully directed from one country to another is a measure of its information aggressiveness. Accordingly, countries which are information leaders in information wars of our time are potential winners.

Modern information wars are waged primarily in the political, economic as well as religious and cultural fields which are closely interrelated in their goals and means. The religious and cultural context of information warfare is based on manipulation of public consciousness archetypes which have a status of the sacred. In due time H.M. McLuhan aptly pointed out that Russia waged information wars with the help of artificially created imagesicons: "to be aggressively effective in the modern world of information, it is sufficient for the Russians to adapt their traditions of Eastern icons and building images to new electric means of communication" [McLuhan, 2011: 173].

Although information wars in the international context are generally aimed at political goals of redistributing power, their ultimate goal in the situation of global commercialization of knowledge as a commodity is to ensure their own economic power. E. Toffler draws attention to economic information wars waged at all levels - personal-managerial, corporate, nationwide and intergovernmental, pointing out that "information is the most dynamic of all resources, and this dynamics is a distinctive feature of the economy where production and distribution of food, energy, goods and services has been ever depending on the exchange of symbols" [Toffler, 2004: 202].

As mentioned above, the modern period of information society development features the formation of knowledge society where human cognitive abilities in assimilating information are implemented to the maximum, which gives rise to a new form of information warfare - psychological. $O$. Senchenko defines the latter as a system of information, propaganda and psychological actions coordinated as to their goals, objectives, place and time, which are carried out with the use of mass media, culture, art and other means (psychotropic, psychotronic) for a long time according to a carefully designed scenario [Senchenko, 2014].

The ultimate goal of psychological warfare is destruction of a stable system of ideological orientations and moral values in public and individual consciousness, their replacement with simulacra - "replacement of the real with real signs, an operation aimed at transformation of any real process through its operational copy, a metastable mechanism of images" [Baudrillard, 2013: 18]. Having introduced the concept of simulacrum in science to designate a specific mode of institutionalization of iconic complexes of existing culture, J. Baudrillard actualized the problem of dangers of new information and communication reality. Absorbing and displacing reality, simulacra no longer form any separate sphere of sign realities at a certain stage of informational civilization development but become a total and universal functioning mode of any sign as such. Any event acts as a sign, its meaning provided by mass media as well as a recipient of information in accordance with the simulacra interpretation system, imposed upon him/her

The theory of mass communications analyzes in detail 
the basic manipulation strategies of modern media, especially television, which, according to M. Castells', exerts social influence of binary nature because if a message has reached television, it may be changed, transformed and even distorted [Castells M., 2000]. M. Castells defines the emergence process of noopolitics (a political dimension of the emergence of a noosphere as global information space encompassing cyberspace and other information systems, for example, media) as a significant problem for ensuring international security. The above process greatly improved manipulative public influence mechanisms which define public behavior models [Castells, 2004: 189].

\section{Conclusions}

An analysis of the phenomenon of information culture in the period of the formation of knowledge society shows that it has to be considered as the main means of an effective operation of complex information systems - states, nations and individuals. Information culture has a general civilizational context, it characterizes a development level of information interaction of all elements of a public information system - political, economic, educational and cultural. Information culture determines a level of operational efficiency of structural units of society (individuals, social groups) in respect of obtaining, conveying, storing and using information in accordance with their information needs and digestion in the form of knowledge in social memory.

The development status of information culture at both individual and national levels is a logical representation of a degree of public safety. Information culture is inseparable from the concept of information value which has an ambivalent content and is defined by its socio-cultural significance in a particular historical period as well as information needs of its consumers. Accordingly, the conditions for the formation of information culture of society require the creation of an appropriate information environment as a new form of being with a specific system of communications which change under the influence of informatization, scientific, technical and sociocultural innovations.

Ensuring the information security of a state requires the creation of an adequate information environment which structurally includes an information potential, information resources and an information infrastructure, which development and operation degree generally govern the development level of information culture of society. At the national level, information culture is implemented as a complex of measures aimed at improving information selfawareness and developing a nationally oriented infor- mation worldview through cooperation of the authorities, educational system as well as social and communication institutions, creation of a system of national information resources by digitizing national cultural heritage, implementation of effective scientific communication mechanisms to promote and further develop the domestic scientific system of knowledge.

At the personal level, information culture is implemented as a new type of communication based on effective acquirement of the latest developments in the information and communication industry and aimed at overcoming various types of information barriers, which provides unhindered access to information resources; an ability to evaluate information from the point of view of its manipulative orientation, capability to meet information needs owing to the established technique for assimilating information resources with the help of traditional and leading-edge information technologies, and, as a result, to shape a new type of thinking that stimulates the striving for self-development and self-learning.

\section{REFERENCES}

Baudrillard, J. 2013. Simulacrum and simulation [translat.]. Tulskiy poligrafist, Tula: 204 p. (rus).

Huntington, S. Ph. 2005. Clash of Civilizations [translat.]. AST. Moscow, $603 \mathrm{p}$

Castells, M. 2000. The Information Age: Economics, Society and Culture. Moscow. GU VShE. 608 p. Available at: https:// www.gumer.info/-bibliotek_Buks/Polit/kastel/05.php (Accessed: 25.09.2018).

Castells, M. 2004. Galaxy Internet: Reflections on the Internet, business and society. U-Faktoriya Publ., Yekaterinburg, $328 \mathrm{p}$. (rus).

Kolin, K. K. 2005. The nature of information and philosophical foundations of computer science. Otkrytoye obrazovaniye. 2. pp. 43-50 (rus).

McLuhan, H. M. 2011. Understanding Media: External Human Expansion [translat.]. Kuchkovo pole Publ., Moscow, 464 p. (rus). Rastorguev, S. P. 1999. Information war. Radio i svyaz. Moscow, 416 p. (rus).

Senchenko, O. 2014. Structure, means and models of using psychological weapons in the system of social communications. Visnyk Knyzhkovoi palaty, No.7: 44-49 (ukr).

Sokolov, A. V. 2010. Philosophy of information. St. Petersburg: SPbGUKI, 368 p. (rus).

Toffler, E. 2004. Metamorphoses of power [translat.]. "Izdatelstvo AST" Ltd, Moscow, 669 p. (rus).

Towards Knowledge Societies: UNESCO World Report. 2005. UNESCO Publishing. Moscow, 231 p. (rus).

Vinarik, L. S. 2009. Information culture in modern society. Mehanizmi regulyuvannya ekonomiky. 2: 80-90 (rus).

Ломачинська Ірина,

доктор філософських наук, професор, професор кафедри філософії, Київський університет імені Бориса Грінченка

\section{ЦІННІСНІ ОРІЄНТИРИ ІНФОРМАЦІЙНОї КУЛЬТУРИ ЯК КЛЮЧОВОГО ФАКТОРА ІНФОРМАЦІЙНОї БЕЗПЕКИ СУСПІЛЬСТВА}

Стаття присвячена аналізу сутності інформаційної культури як основного фрактора безпеки соціальної інформаційної системи перед глобалізаційними викликами інформаційних загроз сучасності. Аналіз проведено із застосуванням системного підходу: інформаційну культуру визначено як засіб функціонування складних інформаційних систем (індивідів, соціальних груп, націй, держав), пов'язаних загальним історичним досвідом, нормами, цінностями, що визначають інтелектуальні та практичні можливості особи сприймати та асимілювати, переробляти, використовувати, передавати інформацію в просторі та в часі. Зазначено, що фрілософське розуміння феномена інформаційної культури дає підстави для розгляду його на кількох рівнях: соціально- 
технічному (це вміння працювати з інформацією); соціокультурному (це сукупність матеріальних і духовних досягнень суспільства); освітньому (це вміння адекватно асимілювати нові знання за допомогою системи освіти, наукової та художньої творчості).

Сутність інформаційної культури визначено як основний засіб становлення інформаційного світогляду суспільства на всіх етапах інформаційно-комунікаційних революцій. Проаналізовано ціннісні орієнтири інформаційної культури в контексті становлення ідеології суспільства знань, а саме: необхідність виховання свідомої особистості, що має стимул до саморозвитку та здатна задовольняти свої інформаційні потреби, як необхідну умову формування інформаційно свідомого суспільства, здатного протистояти загрозам маніпулятивного впливу у інформаційних війнах сучасності.

Визначено сутність інформаційної війни як комунікаційної технології для впливу масової свідомості 3 метою досягнення інформаційної переваги у забезпеченні національної військової стратегії шляхом впливу на інформаційні системи противника при зміцненні та захисті власних інформаційних систем. Відзначено, що стратегія використання інформаційної зброї є наступальною агресією, тому можна припустити, що обсяг інформації, що надсилається 3 однієї країни в іншу, є мірою його інформаційної агресивності; відповідно, країниінформаційні лідери в інформаційних війнах нашого часу потенційно переможці. Сучасна інформаційна війна спрямована на перепрограмування суспільної свідомості відповідно до бажань агресора.

Інформаційні війни здійснюються через систему інформаційно-пропагандистської та психологічної діяльності, що здійснюється із застосуванням засобів масової інформації шляхом маніпулювання релігійними та культурними архетипами суспільної свідомості.

У висновку зазначено, що забезпечення інформаційної безпеки держави вимагає створення інформаційного середовища, що включає інформаційний потенціал, інформаційні ресурси та інформаційну інфраструктуру, ступінь розвитку та функціонування якої залежить від рівня розвитку інформаційної культури суспільства.

У статті підкреслюється необхідність виховання свідомої людини, яка має стимул для саморозвитку та здатна задовольнити свої інформаційні потреби. Культура інформації про особистість - це дослідження останніх подій у галузі інформаційних технологій, вміння оцінювати інформацію з точки зору маніпулятивної орієнтації; це є передумовою формування інформаційно свідомого суспільства, здатного протистояти загрозам інформаційно-психологічного впливу в інформаційних війнах нашого часу.

Ключові слова: інформаційне суспільство; суспільство знань; інфрормаційна культура; інформаційна система; інформація; інформаційна війна; консцієнтальна війна; інформаційний світогляд.

\section{ЛПЕРАТУРА}

Бодрияр Ж. Симулякры и симуляция. Тула: Тульский полиграфист, 2013. 204 с.

Винарик Л. С. Информационная культура в современном обществе. Механізми регулювання економіки. 2009. № 2. С. 80-90. Гантингтон С. Столкновение цивилизаций. Москва: АСТ, 2005. 603 с.

К обществам знания: Всемирный доклад ЮНЕСКО. Б.М.: Изд-во ЮНЕСКО, 2005. 231 с.

Кастельс М. Информационная эпоха: экономика, общество и культура. Москва: ГУ ВШЭ, 2000. 608 c. URL: ttps:// www.gumer.info/bibliotek_Buks/Polit/kastel/05.php (дата звернення: 25.09.2018).

Кастельс М. Галактика Интернет: Размышления об Интернете, бизнесе и обществе. Екатеринбург: У - Фактория, 2004. 328 c.

Колин К. К. Природа информации и философские основы информатики. Открытое образование. 2005. № 2. С. 43-50.

Маклюэн Г. М. Понимание медиа: Внешнее расширение человека. 3-е изд. Москва: Кучково поле, 2011. 464 с.

Расторгуев С. П. Информационная война. Москва: Радио и связь, 1999. 416 с.

Сенченко О. Структура, засоби і моделі застосування консцієнтальної зброї в системі соціальних комунікацій. Вісник Книжкової палати. 2014. № 7. С. 44-49.

Соколов А. В. Философия информации. Санкт-Петербург: СПбГУКИ, 2010. 368 с.

Тоффлер Э. Метаморфозы власти. Москва: ООО "Издательство АСТ", 2004. 669 с.

(c) Lomachinska Irina

Надійшла до редакції 28.09.2018 